\title{
マイクロレンズアレイを用いた表面プラズモン共鳴による膜厚分布測定
}

\author{
兼岡 良樹 ${ }^{* 1}$, 坂下 竜一 ${ }^{* 1}$, 水谷 康弘 ${ }^{* 2}$, 岩田 哲郎 ${ }^{* 3}$
}

\section{Measurement of film thickness distribution by surface plasmon resonance using a micro-lens array}

\author{
Yoshiki KANEOKA $^{* 1}$, Ryoichi SAKASHITA ${ }^{* 1}$, Yasuhiro MIZUTANI ${ }^{* 2}$ and Tetsuo IWATA*3 \\ ${ }^{* 1}$ Graduate School of Advanced Technology and Science, Tokushima University \\ 2-1 Minamijosanjima-cho, Tokushima-shi, Tokushima 770-8506, Japan \\ ${ }^{* 2}$ Department of Mechanical Engineering, Osaka University \\ 2-1 Yamadaoka, Suita-shi, Osaka 565-0871 Japan \\ ${ }^{* 3}$ Institute of Technology and Science, Tokushima University \\ 2-1 Minamijosanjima-cho, Tokushima-shi, Tokushima 770-8506, Japan
}

\section{Received 22 May 2015}

\begin{abstract}
In order to measure the two-dimensional distribution of the thickness of a metal layer coated on a dielectric layer at a time, we propose to use a micro-lens array (MLA), instead of a conventional single plano-convex lens, by which lots of surface-plasmon-resonance (SPR) dip patterns could be observed from a modified Otto configuration. The individual micro lenses produce circular ring-shaped SPR dip patterns in reflection, which enable us to estimate the thickness of the metal with high sensitivity and precision with ease. A spatial resolution is determined by the size of each lens and is $300 \mu \mathrm{m}$ in diameter. As a proof-of the principle experiment, we measured the thickness of a 50nm-thickness Au film with precision $\pm 0.9 \mathrm{~nm}$ for an area of $2.7 \mathrm{~mm} \times 2.7 \mathrm{~mm}$. A method for improving the spatial resolution further is discussed.
\end{abstract}

Key words : Surface plasmon resonance, Microlens array, Modified Otto configuration, Thin film measurement, Thickness distribution

\section{1. 緒言}

半導体電子部品，あるいは光半導体素子などの製造工程においては，例えばガラスなどの誘電体媒質上に蒸着 されたナノオーダの金属薄膜の厚さの二次元的な一様性，すなわち膜厚分布を正確かつ精度よく，しかも高速か 簡便に評価する手法が求められている(Macleod，1986)，金属の種類としては，金，銀，銅，アルミニウムなど が一般的である．そのための測定手法としては，電磁誘導に基づく接触式膜厚計を用いる方法，超音波を用いる 手法，スペクトル干渉を用いる方法などがある(Placko, et al., 1989; Flournoy, et al., 1972). しかし，前者 2 つは接触 測定が前提であり，膜厚検出下限もマイクロオーダに留まっている．膜厚が十分薄いと仮定するとスペクトル干 渉測定が行えるが，やはり波長以下の測定精度は得にくいのが実情である，そこで，そのようなオーダの膜厚を 測定する場合にはエリプソメータの採用を検討寸ることになる.エリプソメータではサブナノオーダの測定が精 度よく行え，場合によっては膜の複素屈折率も推定できる(Azzam and Bashara, 1989). しかし，測定対象に対する 正確な光学モデルを必要とし，測定の信頼性を向上させようと思えば，入射角度や波長を変化させる必要も時に は生じる．結果として装置は大がかりで高価となってしまう．何よりたとえこれをクリアしたとしても，膜厚の 二次元分布の取得のためには，試料を二次元に掃引する必要があり，測定に時間がかかってしまう。

このような問題を解決するための手法の一つとして, 表面プラズモン共鳴(SPR: Surface Plasmon Resonance)の利

No.15-00291 [DOI:10.1299/transjsme.15-00291], J-STAGE Advance Publication date : 9 September, 2015

*1 徳島大学大学院 先端技術科学教育部（言770-8506 徳島県徳島市南常三島町 2-1）

$*_{2}$ 大阪大学 大学院工学研究科（广565-0871 大阪府吹田市山田丘 2-1）

*3 正員, 徳島大学 大学院ソシオテクノサイエンス研究部

E-mail of corresponding author: mizutani@mech.eng.osaka-u.ac.jp 
用が考えられる(Rothenhäusler and Knoll, 1988). SPR とは，金属原子の自由電子の縦波プラズマ振動の波数と入射 $p$ 偏光の金属表面に平行な波数成分とが金属表面と周囲の誘電体媒質間の境界で共鳴カップリングする現象であ る．それが生じると反射光強度が低下寸る．したがって，入射光角度を変化させながら反射光強度を入射角の関 数としてプロットすれば（そのプロットを反射光角度スペクトルと呼ぶ）共鳴ディップが現れる. 共鳴条件は金 属薄膜の膜厚とその複素屈折率, および周囲の誘電体媒質の複素屈折率に依存しているため, すべての複素屈折 率が既知であれば，測定した反射光角度スペクトルの共鳴ディップの位置のシフトや形状から膜厚を推定するこ とができる．このように，SPRでは簡単な反射光強度測定をしているのにもかかわらず，測定精度と感度はエリ プソメータのそれらに匹敵することが確認されている(Salvi and Barchiesi, 2014).

SPR を発生させるための光学系としては, Kretchmann 配置と Otto 配置の 2 つがある(Kretschmann, 1971; Otto, 1968). Kretchmann 配置の基本形は, ガラス層, 金属, 誘電体媒質の三層系で構成される. 一方, Otto 配置はガ ラス層, 空気層, 金属, 基板からなる 4 層系となる。ここで，金属薄膜自身の測定のためには，空気層がプリズ ムと金属間にいわばバッファ層として入る Otto 配置が適している. しかし SPR を発生させるためには，その空 気層の厚さをナノオーダで制御する必要がある.この問題を緩和する手法として, 変形 Otto 配置光学系がある (Bliokh, et al., 2006).これは, Otto 配置のガラス層として平凸レンズを用いる. 平凸レンズを用いるため空気層の 厚さはレンズの曲面に沿って変化する．したがって，SPRの発生に必要な空気層の厚さを機械的制御することな しにナノオーダで連続的に変えられる.このとき, 共鳴条件を満たす厚さの空気層の位置での反射率ディップ形 状は同心円環状となる．最終的に，環状に現れた反射光の強度分布を測定することでその位置での金属膜厚を推 定することができる.これまでに, 我々は変形 Otto 配置光学系にエリプソメータの光学系を導入して, 数 $10 \mathrm{~nm}$ 数 $100 \mathrm{~nm}$ の金属膜上の誘電体膜の厚さを $1 \mathrm{~nm}$ 以下の精度で測定できることを報告した(Iwata and Mizutani, 2010 ; Mizutani and Iwata, 2011). さらに平凸レンズの代わりにシリンドリカルレンズを用いて 2 本の平行な直線のディッ プでも測定ができることを示した(Iwata et al., 2011). しかし，環状に現れる強度分布 1 つにつき測定できる膜厚の 数は 1 つであるため, 膜厚の分布を測定するにはサンプルを走査する必要があった. また, エリプソメータの導 入は測定の精度を向上させられるものの，冒頭に述べたような金属薄膜の膜厚二次元分布測定の目的にはやや才 ーバスペックである.

以上の問題点を解決するために, 我々は, 微小レンズの集合体であるマイクロレンズアレイ(MLA: Micro Lens Array)に着目した。 寸なわち, 変形 Otto 配置で用いるレンズとして, 従来の単一平凸レンズの代わりに MLA を 用い, それぞれのマイクロレンズ毎に, 微小環状のSPR 共鳴ディップを二次元平面上で規則的に多数個発生させ た．その結果，走査することなくレンズのサイズとその曲率半径に応じた空間分解で膜厚分布が推定できるよう になった. 本報告では, エリプソメータの光学系を導入せずに MLA を用いた変形 Otto 配置光学系で, 厚さ $50 \mathrm{~nm}$ の金の膜厚分布をナノオーダの精度で空間分解 $300 \mu \mathrm{m}$ 程度で測定できることを示す.

\section{MLA を用いた膜厚測定原理}

図 1 (a)に, MLA を用いた変形 Otto 配置によるSPR 発生の様子を示寸. 試料は，ガラス基板上に製膜された金 属薄膜であり，MLA とわずかな厚みの空気層を挟んで配置されている. また，ここでは金属薄膜が階段状の膜厚 を有すると仮定している. 図 1 (b)に，このときのエネルギ反射率分布を示す. 変形 Otto 配置に MLAを用いるた め, 各レンズに対して環状の共鳴ディップが現れている. また, 膜厚の変化に応じて共鳴ディップの形状が異な る.したがって，共鳴ディップを個別に評価することで膜厚の分布を測定できる.

ここで, サンプル面上の位置 $(x, y)$ におけるエネルギ反射率 $R(x, y)$ は,

$$
R(x, y)=\left|\frac{r_{12}\left[1+r_{23} r_{34} \exp \alpha_{3}\right]+\left[r_{23}+r_{34} \exp \alpha_{3}\right] \exp \alpha_{2}}{1+r_{23} r_{34} \exp \alpha_{3}+r_{12}\left[r_{23}+r_{34} \exp \alpha_{3}\right] \exp \alpha_{2}}\right|^{2}
$$

となる.ここで， $\alpha_{\mathrm{n}}$ は， 


$$
\alpha_{\mathrm{n}}=2 i \sqrt{\varepsilon_{\mathrm{n}} k_{0}^{2}-k_{\mathrm{x}}^{2}} h_{\mathrm{n}}
$$

である. $r_{\mathrm{n}(\mathrm{n}+1)}$ は各層間の反射係数, $h_{\mathrm{n}}$ は各層の膜厚, $\varepsilon_{\mathrm{n}}$ は各層の誘電率， $k_{0}$ は測定光の波数， $k_{\mathrm{x}}$ は界面に角度 $\theta$ で入射する光の界面方向の波数である(Iwata and Mizutani, 2010). 式(1)および(2)からわかるように，R(x,y)はサン プルの膜厚に依存するため, 複素誘電率が既知であれば反射光強度から膜厚を推定できる. 本研究では, 膜厚を 求めるために, 環状の反射光強度減衰領域の中心を通る断面の強度分布と式(1)より算出した理論曲線とのフィッ ティングを行った.

(a)

$$
\text { incident light }
$$

(p-polarization)

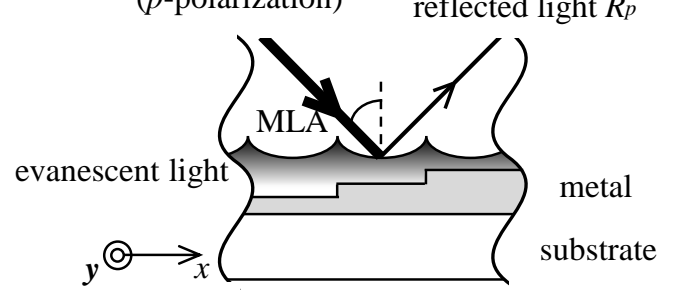

(b)

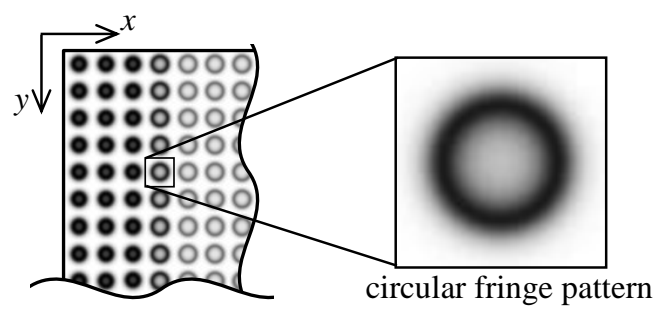

Fig. 1 (a) A schematic diagram of the modified Otto's configuration using MLA, (b) a two-dimensional fringe pattern obtained from the configuration shown in (a).

\section{3. 数值計算による測定条件の決定}

金属薄膜の膜厚を推定するためにはそれ以外のパラメータが既知である必要がある。そこで，入射波長，入射 角および空気層厚さを決定するために，エネルギ反射率の入射角および波長依存性とエネルギ反射率の空気層厚 さおよび入射角依存性を, 式(1)および(2)をもとに数值計算により確認した. 図 2 に, 数值計算に用いた光学モデ ルを示す．このモデルはBK7 プリズム，MLA，空気層，Au 薄膜およびガラス基板の 5 層で構成されている。ま ずは，入射波長と入射角を変数としてエネルギ反射率を算出した。図 3 に，数值計算により得られたエネルギ反 射率の入射角および波長依存性を示す。図 3 より, 臨界角より小さい角度では波長が $400 \mathrm{~nm}$ から $600 \mathrm{~nm}$ 付近で エネルギ反射率が小さいことがわかる.これは，この波長域で SPR に依らず金が光を吸収するためである.一方， 入射角が $45 \mathrm{deg}$. 付近に着目すると, 波長が $600 \mathrm{~nm}$ から $800 \mathrm{~nm}$ の範囲で急峻な吸収ディップを有する領域がある. この吸収が SPR に依るものである。そこで，本研究では波長 $632.8 \mathrm{~nm}$ の He-Ne レーザを用いることにした.

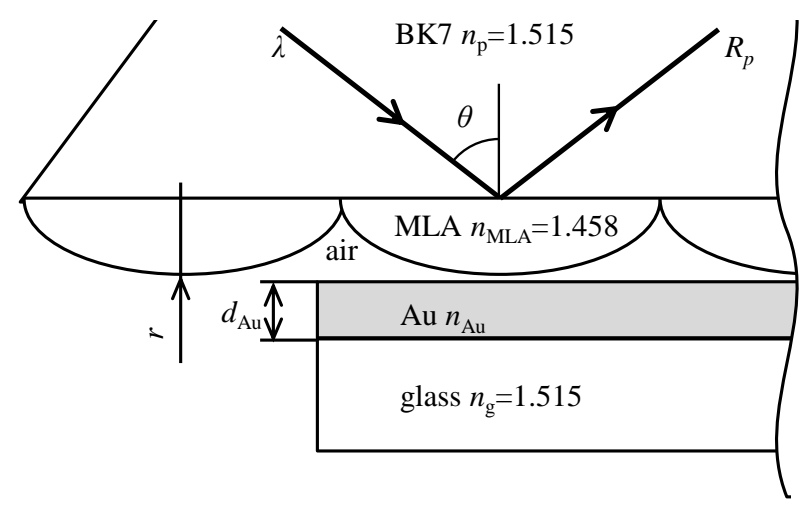

Fig.2 An optical model used for numerical simulations. 


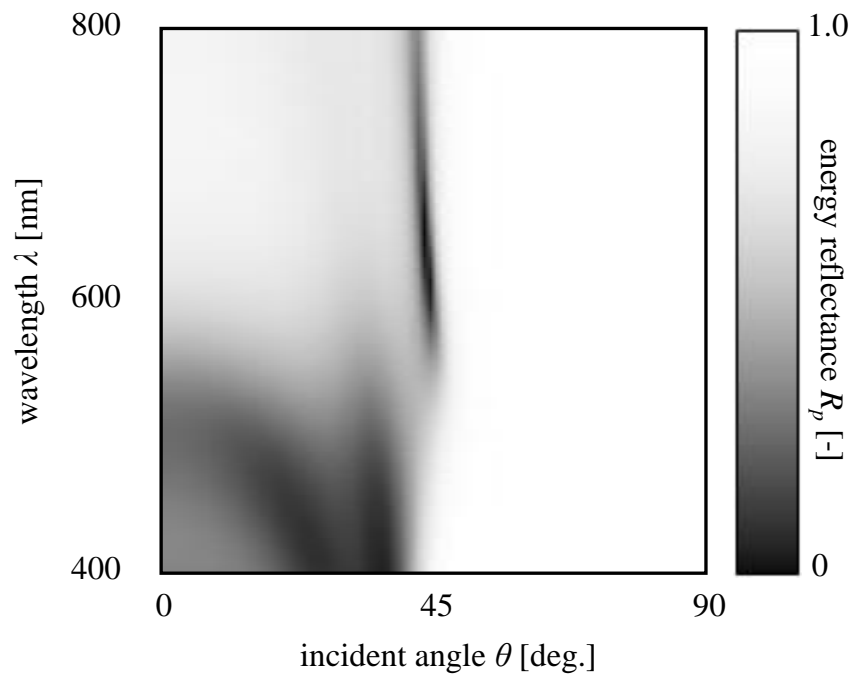

Fig. $3 R_{p}$ as functions of $\theta$ and $\lambda$, where $d_{\mathrm{Au}}=50 \mathrm{~nm}$ and the thickness of the air gap is $500 \mathrm{~nm}$.

次に，入射波長を $632.8 \mathrm{~nm}$ に固定し，エネルギ反射率の空気層厚さおよび入射角依存性を確認した．図 4 に, エネルギ反射率の空気層厚さおよび入射角依存性の数值計算結果を示寸．このとき， $\mathrm{Au}$ の複素屈折率は $n_{\mathrm{Au}}=$ 0.172+3.440i とした. 図 4 より, 空気層の厚さが $1000 \mathrm{~nm}$ を超えるとエネルギ反射率が大きく下がっている部分 が確認できないため，この領域では SPR が発生しないことがわかる．また，エネルギ反射率が最小となるのは， 入射角が $43 \mathrm{deg}$, 空気層の厚さが $448 \mathrm{~nm}$ のときであることを確認した. このことから, 変形 Otto 配置において, 空気層の厚さが $448 \mathrm{~nm}$ の点で SPR による吸収ディップが発生すれば，金の膜厚が $50 \mathrm{~nm}$ であると評価すること が可能となる.このことから, 本研究では, 入射角をエネルギ反射率が最小となる $43 \mathrm{deg}$., 空気層厚さを SPRが 発生する $0 \sim 1000 \mathrm{~nm}$ 程度とした。

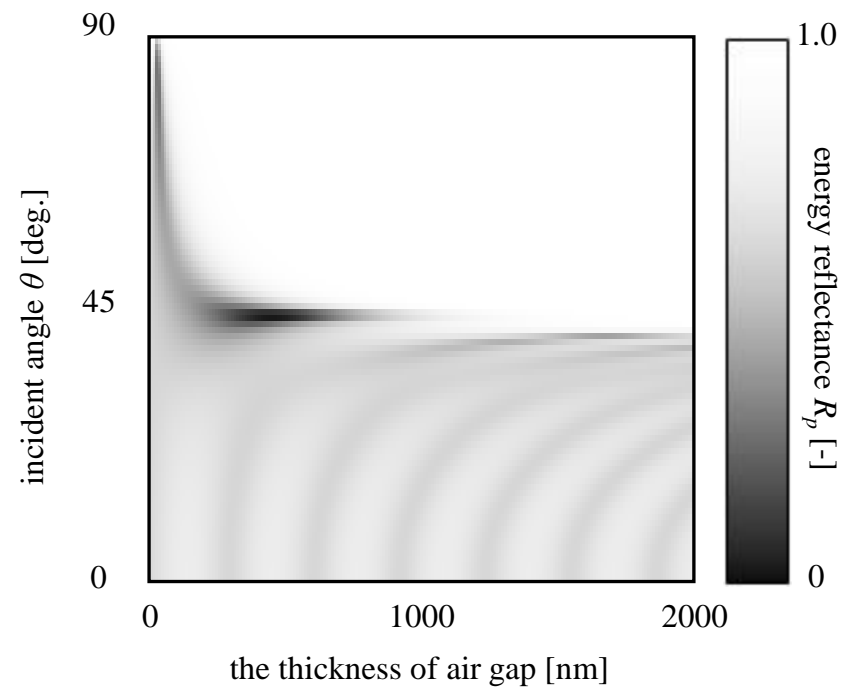

Fig. $4 R_{p}$ as functions of the thickness of the air gap and $\theta$, where $d_{\mathrm{Au}}=50 \mathrm{~nm}$ and $\lambda=632.8 \mathrm{~nm}$.

以上のように算出した空気層厚さが，本実験で今回使用する MLA により満たされているかを確認するために MLA の表面形状を白色干渉計により測定した．図 5 に，白色干渉計により測定した MLA の表面形状を示す．測 定は，白色干涉計である非接触表面形状測定機（Zygo 社：Nexview）を用いて測定した. 図 5 より，複数配列さ れたレンズの曲面が確認でき，レンズの直径は $300 \mu \mathrm{m}$ ，曲率半径は $8.4 \mathrm{~mm}$ であった．また，レンズの厚さは 1.37 
$\mu \mathrm{m}$ であった，よって，所望の空気層厚さが得られる。この結果をもとに，金属薄膜の膜厚に対するエネルギ反 射率の変化を数值計算により検討した．金の膜厚を 49,50 および $51 \mathrm{~nm}$ としてエネルギ反射率の数值計算を行 った. 図6 (a)および(b)に，算出したエネルギ反射率およびエネルギ反射率に対する金薄膜の膜厚依存性の計算結 果をそれぞれ示す．図6 (a)に示寸とおり，レンズ端から 70 および $230 \mu \mathrm{m}$ 離れた領域でエネルギ反射率が低下し ている.さらに, 図 6 (a)の実線で囲んだ領域を拡大した図 6 (b)に着目すると, 各膜厚でエネルギ反射率曲線の形 状に差が生じていることがわかる，このことより，MLA を用いた場合のエネルギ反射率は $1 \mathrm{~nm}$ 程度の変化に対 して感度があることがわかる，さらに，膜厚の測定可能範囲について定量的に評価するために，極小值に着目し 数值計算をした．図 7 に, エネルギ反射率の最小值の金膜厚依存性の計算結果を示す. 縦軸にエネルギ反射率の 最小值，横軸に金膜厚を示寸．図 7 より，膜厚の増加によりエネルギ反射率の最小值も増加していることがわか る. また，膜厚が $25 ~ 70 \mathrm{~nm}$ の範囲において変化量が大きくなっていることから，金膜厚が $25 \sim 70 \mathrm{~nm}$ の範囲で膜 厚測定が可能であることがわかる.

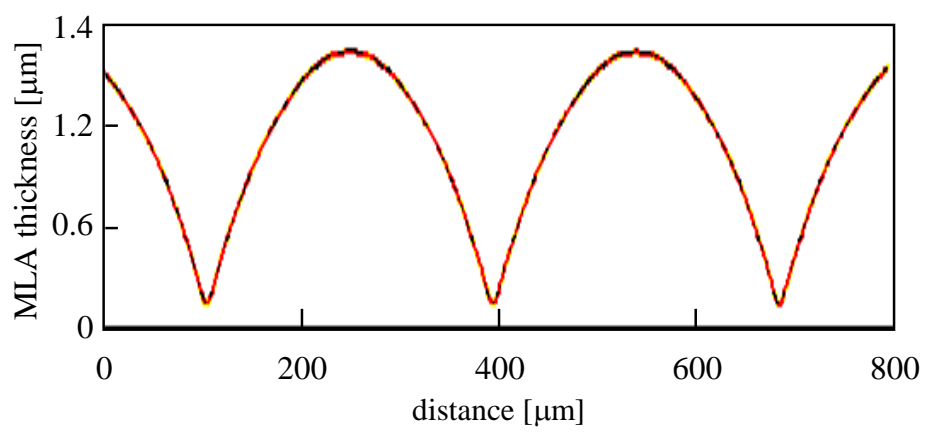

Fig. 5 A surface profile of MLA.
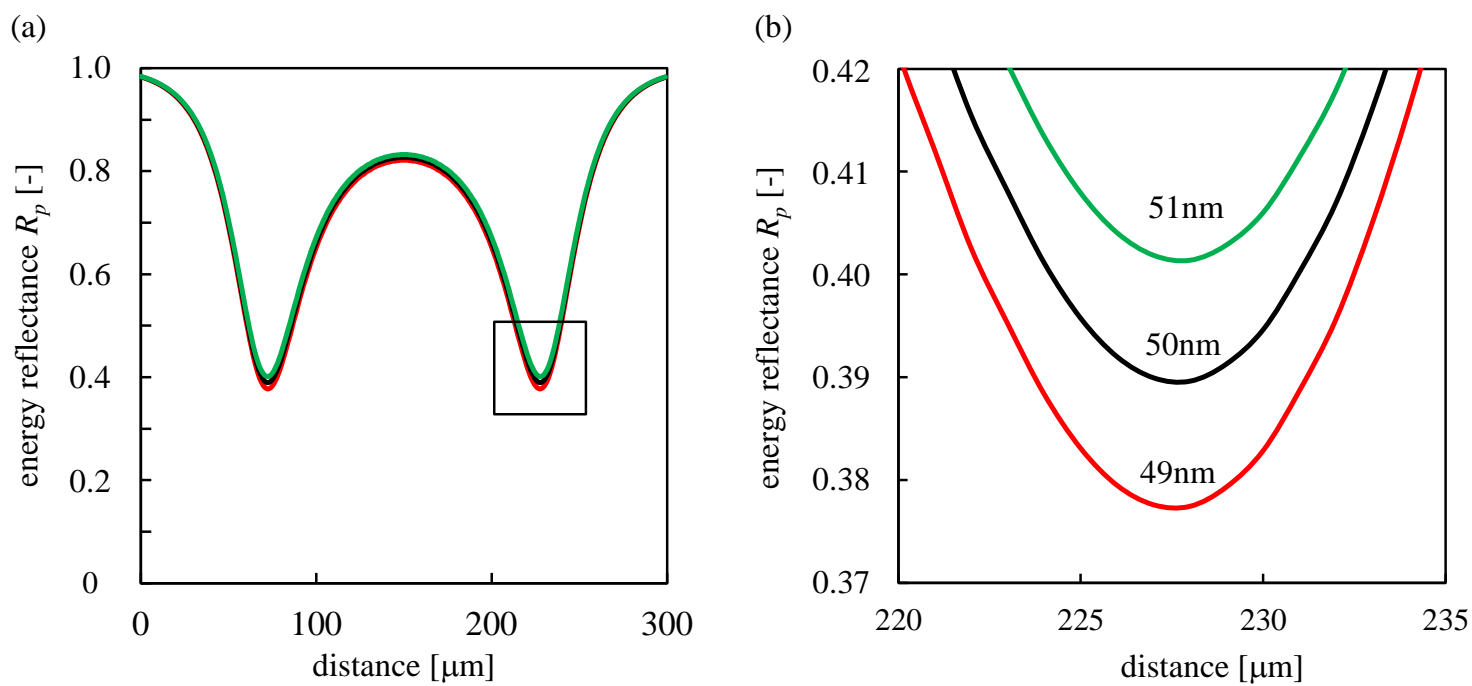

Fig. 6 (a) $R_{p}$-dip patterns for $d_{\mathrm{Au}}=49,50$ and $51 \mathrm{~nm}$, and (b) enlarged view of (a). 


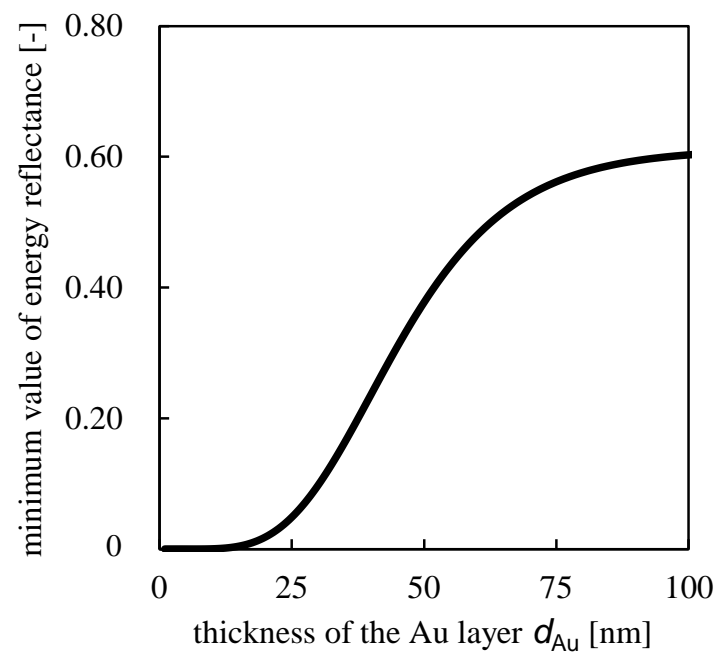

Fig. 7 Minimum value of $R_{p}$ as a function of $d_{\mathrm{Au}}$.

\section{MLA を用いた膜厚の分布測定システム}

数值計算により得られた条件をもとに測定システムを構築した．図8に，MLAを用いた変形Otto配置による膜 厚分布測定システムを示す．光源には，波長 $632.8 \mathrm{~nm}$, 出力 $10.0 \mathrm{~mW}$ の He-Neレーザを用いた. 光源から出射され た光は，15倍のコリメータレンズを用いてビーム径を拡大して $12 \mathrm{~mm}$ とし，回転拡散板を用いてスペックルノイ ズを除去した後に，偏光子を用いてp偏光にし，プリズムおよびMLAに入射させた．なお，MLAは，マッチング オイルを用いてプリズムと光学接触させている．試料は，数值計算と同様に厚さが50 $\mathrm{nm}$ 金薄膜を用い，MLA に接触するように設置した，MLAで反射した光をレンズおよびCCDカメラを用いて検出した.

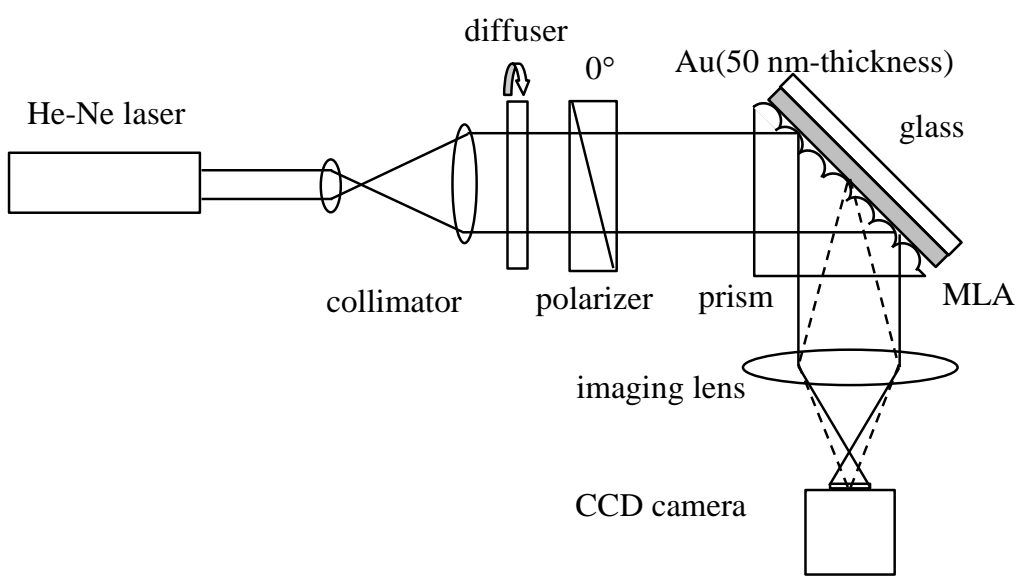

Fig. 8 A schematic diagram of the optical system.

\section{5. 変形 Otto 配置を用いたSPR による金属膜厚の分布測定}

まず，測定原理確認のため，本報告で用いた MLA に比べサイズが十分に大きい単レンズを用いて膜厚を測定 した．単レンズのレンズ直径は $30 \mathrm{~mm}$ ，曲率半径は $259.5 \mathrm{~mm}$ のものを用いた．図 9 に，エネルギ反射率の測定 結果を示す. 図 9 (a)に, 取得した画像を示し, 図 9 (b)に, 図 9 (a)の Y-Y’断面のエネルギ反射率分布を示す. 点 線は測定值および実線はフィッティング曲線である。このフィティング曲線は測定值と理論曲線との残差二乗和 を最小化させることにより得た．また，エネルギ反射率の理論曲線は，与えられたレンズの幾何学的形状から断 面に沿った空気層の厚さが算出できるため，プリズムルンズ/空気/金薄膜/ガラス基板の 5 層系として求めた. 図 9 (a)より，エネルギ反射率が低下している部分が環状になっていることが確認できる．このことから，環状の部 
分で SPR が発生していることがわかる. 図 $9(b)$ より，金の膜厚を算出すると $50.0 \mathrm{~nm}$ となり，サンプルの厚さ 50 $\mathrm{nm}$ とよい一致を示した．このことより，変形 Otto 配置を用いて膜厚が測定可能であることを確認した.

(a)

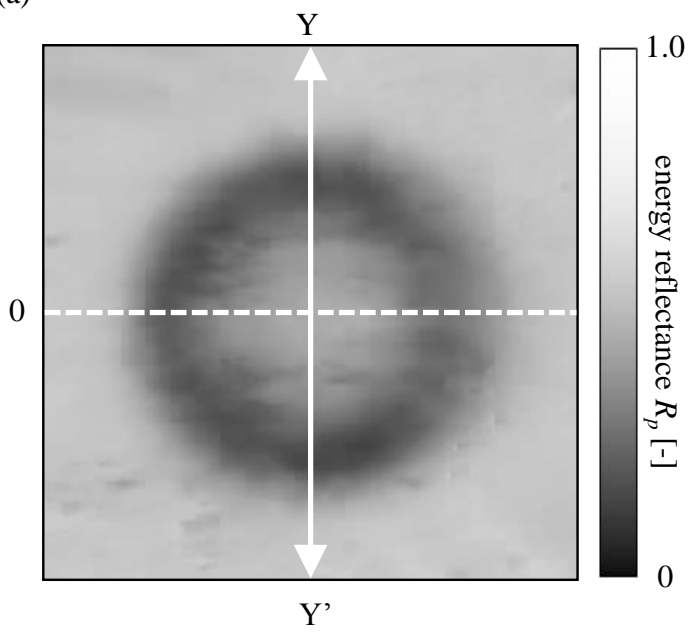

(b)

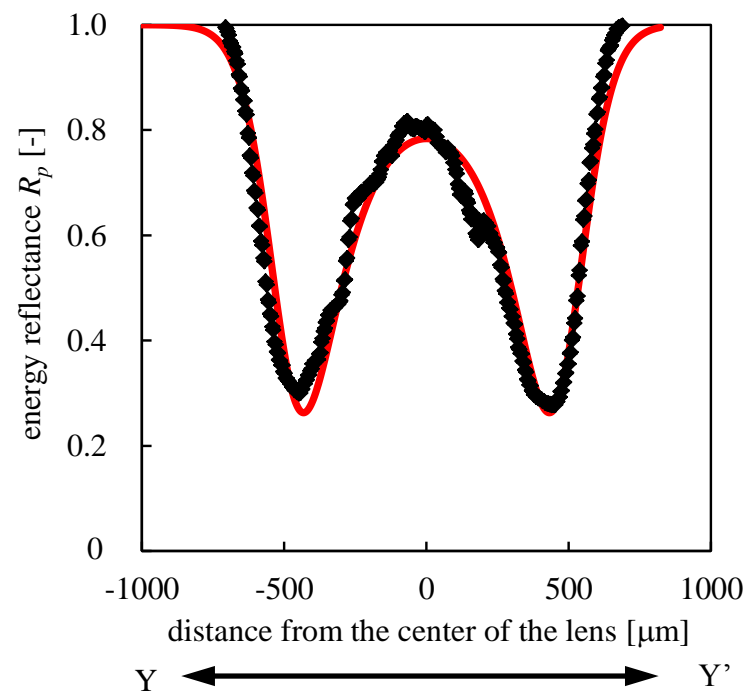

Fig. 9 (a) A two-dimensional fringe pattern due to the conventional SPR obtained from the modified Otto-configuration, and (b) the $R_{p}$-profile along the Y-Y' cross section depicted in (a).

単レンズを用いた膜厚測定が可能であることを確認したため, MLA を用いて反射率の分布を取得し，金薄膜の 膜厚の分布を測定した. 図 10 (a)に, 9×9 個に配列されたレンズの領域でのエネルギ反射率の分布を示す. 図 10 (a) より，エネルギ反射率が環状に低下している箇所が 9×9 箇所確認できた。これは，SPRに起因した環状の分布で ある図 10 (b)に，各環状のエネルギ反射率分布と理論曲線とのフィッティングから膜厚を算出した結果を示す. 9×9 の領域の金膜厚の平均值は $49.8 \mathrm{~nm}$, 標準偏差は $0.9 \mathrm{~nm}$ となり, 設計值に近い值となった. 図 5 の測定で用 いた非接触表面形状測定機を用いて，このようなナノメートルオーダの 2 次元膜厚分布を求めるのは精度的にか なり難しいと思われる．以上より，本システムを用いて膜厚の分布測定が可能であることを示した.

(a)

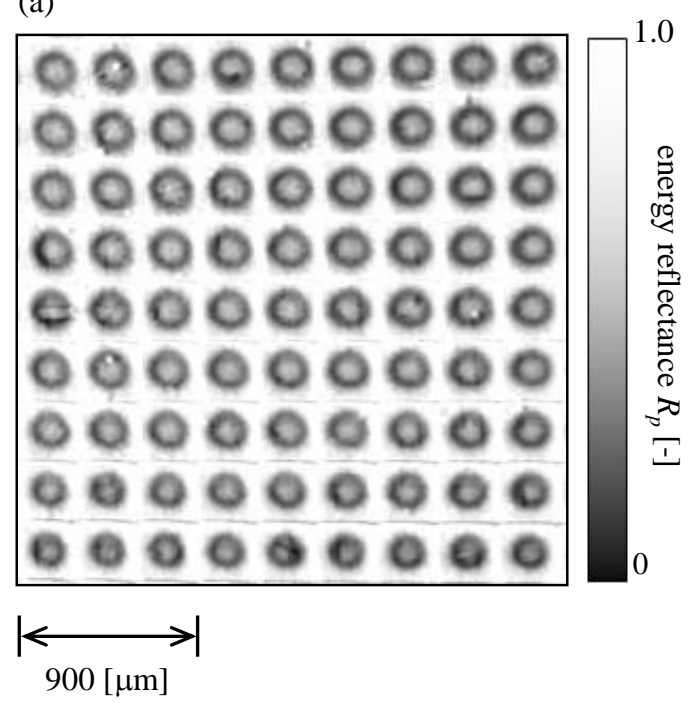

(b)

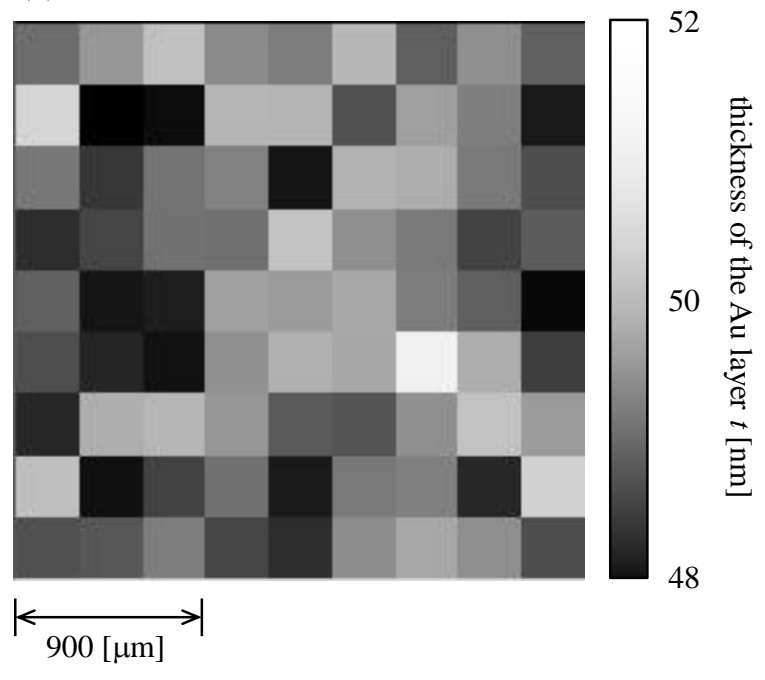

Fig. 10 (a)A two-dimensional fringe pattern obtained from the modified Otto-configuration using MLA, and (b) a two-dimensional Au film thickness distribution calculated from (a). 


\section{6. 結}

MLA を用いた SPRによる膜厚分布測定法を提案した. 原理確認のため, レンズ直径 $30 \mathrm{~mm}$, 曲率半径 $259.5 \mathrm{~mm}$ の単レンズを用いて膜厚を測定した。測定值は $50.0 \mathrm{~nm}$ となり設計值と一致した。レンズ直径 $300 \mu \mathrm{m}$ の MLA を 用いた変形 Otto 配置で 9×9 箇所の SPR の発生を確認した. 測定領域での平均値および標準偏差は $49.8 \pm 0.9 \mathrm{~nm}$ で あり, 設計值 $50 \mathrm{~nm}$ に近い值となった. その結果, MLA を用いた変形 Otto 配置光学系を用いて膜厚の 2 次元分 布計測が可能であることを示した．なお，本報では原理検証のため試料として金薄膜自身の膜厚を測定した。し かし，適切な光学モデルが仮定できれば，金薄膜上にコートされた誘電体薄膜試料の膜厚や複素屈折率測定が可 能であるのは明らかである. 本実験では示せなかったが, MLA もしくは試料を回転させて複数回の測定結果の比 較や再現性の検証が行える高精度な機構が用意できたならば，さらに測定結果の信頼性が向上したはずである. 今後は，それらも含めて MLAの直径をさらに小さくすることで, 空間分解能の向上が期待できる. また, MLA 直径を検出器の素子サイズ程度まで小型化することで反射光強度が平均化される. その場合, もはや円環状のデ イップパターンは消失し, 試料厚さに応じた濃淡画像となる. しかしそのような状況でもその濃淡に応じて膜厚 分布が推定できる.

\section{References}

Azzam, R. M. A. and Bashara, N. M., Ellipsometry and pilarized light, North Holland, Amsterdam (1989).

Bliokh, Yu. P., Vander, R., Lipson, S. G. and Felsteiner, J., Visualization of the complex refractive index of a conductor by frustrated total internal reflection, Applied Physics Letters, Vol.89 (2006), 021908-1-3.

Flournoy, P. A., McClure, R. W. and Wyntjes, G., White-light interferometric thickness gauge, Applied Optics, Vol. 11 (1972), pp.1907-1915.

Iwata, T. and Mizutani, Y., Ellipsometric measurement technique for a modified Otto configuration used for observing surface-plasmon resonance, Optics Express, Vol.18 (2010), pp.14480-14487.

Iwata, T., Wada, Y., Nishigaki, K. and Mizutani, Y., Two-dimensional thickness measurement of a dielectric thin layer on a metal by use of surface-plasmon-resonance-based ellipsometry, Proceedings of SPIE, Vol.8169 (2011), 816913-1-8.

Kretschmann, E. Z., Die Bestimmung optischer konstanten von mettlen duch anregung von oberfla" chenplasmaschwingungen. Zeitschrift für phsik, Vol. 241 (1971), pp. 313-324.

Macleod, H. A., Thin-film optical filters, Bristol, Hilger (1986).

Mizutani, Y. and Iwata, T., Thin film thickness measurement by surface plasmon resonance using a modified Otto's configuration combined with ellipsometry, International Journal of Automation Technology, Vol.5 (2011), pp. 236-240.

Otto, A., Excitation of nonradiative surface plasma waves in silver by the method of frustrated total reflection, Zeitschrift für phsik, Vol.216 (1968), pp.398-410.

Placko, D., Clergot, H. and Santander, E., Physical modelling of an eddy current sensor desined for real time distance and thickness measurement in galvanization industry, IEEE Transactions on Magnetics, Vol. 25 (1989), pp. 2861-2863.

Rothenhäusler, B. and Knoll, W., Surface-plasmon microscopy, Nature, Vol.332 (1988), pp.615-617.

Salvi, J. and Barchiesi, D., Measurement of thicknesses and optical properties of thin films from Surface Plasmon Resonamce (SPR), Applied Physics A, Vol.115 (2014), pp.245-255. 